\title{
Ecophysiological differentiation of Capitella capitata (Polychaeta). Sibling species from different sulfidic habitats
}

\author{
I. Gamenick ${ }^{1,4}{ }^{*}$, B. Vismann ${ }^{2}$, M. K. Grieshaber ${ }^{3}$, O. Giere ${ }^{4}$ \\ ${ }^{1}$ Department of Life Sciences and Chemistry, Roskilde University, Postbox 260, DK-4000 Roskilde, Denmark \\ ${ }^{2}$ Marine Biological Laboratory, University of Copenhagen, Strandpromenaden 5, DK-3000 Helsinger, Denmark \\ ${ }^{3}$ Institut für Zoophysiologie, Heinrich-Heine-Universität, Universitätsstraße 1/26.12, D-40225 Düsseldori, Germany \\ ${ }^{4}$ Zoologisches Institut und Zoologisches Museum, Universität Hamburg, Martin-Luther-King Platz 3, D-20146 Hamburg, Germany
}

\begin{abstract}
The ecophysiological differences of 4 sibling species of the Capitella capitata species complex from habitats with different sulfide concentrations were studied: Capitella sp. S (small) from a North Sea intertidal flat, living in the upper sediment layer containing low sulfide concentrations (up to $20 \mu \mathrm{mol} \mathrm{l}^{-1}$ ); Capitella sp. L (large), sympatric to Capitella sp. S, but living in deeper sediment layers with high sulfide concentrations (up to $350 \mu \mathrm{mol} \mathrm{I}^{-1}$ ); Capitella sp. M from the Mediterranean Sea from highly sulfidic sediments (up to $710 \mu \mathrm{mol} \mathrm{l}^{-1}$ ) close to shallow hydrothermal vents; and Capitella sp. I from eutrophicated coastal areas of the North Atlantic. Capitella sp. L, Capitella sp. M and Capitella sp. I are significantly more tolerant to anoxia and $760 \mu \mathrm{mol} \mathrm{l}^{-1}$ sulfide than Capitella sp. S from the upper North Sea sediments. Respiration rates showed that only Capitella $\mathrm{sp}$. S can be characterized as an oxyconformer. The oxygen consumption of Capitella sp. S becomes successively reduced with declining ambient oxygen tensions. The 3 other sibling species are all oxyregulators with different regulation abilities. At moderate oxygen concentrations the aerobic metabolism of Capitella sp. $\mathrm{S}$ is inhibited at low sulfide levels $\left(30 \mu \mathrm{mol} \mathrm{l}^{-1}\right)$. Conversely, at moderate oxygen levels the anaerobic metabolism of Capitella sp. S is increased at $20 \mu \mathrm{mol} \mathrm{l}^{-1}$ sulfide. In contrast, even at sulfide concentrations of $130 \mu \mathrm{mol}$ $1^{-1}$, the aerobic metabolism of Capitella sp. $\mathrm{L}$ is not affected. The anaerobic metabolism of Capitella sp. $\mathrm{L}$ is not increased at sulfide concentrations $<100 \mu \mathrm{mol} \mathrm{l}^{-1}$. The anaerobic metabolism of Capitella sp. M from the hydrothermal vents is not affected even at higher sulfide concentrations. This study shows that sibling species of the $C$. capitata complex from different habitats can be differentiated by their ecophysiological characteristics.
\end{abstract}

KEY WORDS: Capitella capitata S Sibling species - Sulfide - Anoxia - Tolerance - Oxygen consumption . Anaerobic metabolism

\section{INTRODUCTION}

The cosmopolitan endobenthic polychaete Capitella capitata (Fabricius) is known as an indicator for organically polluted and disturbed marine environments. $C$. capitata dominates the macrobenthic community in areas which are highly eutrophicated by paper mills (Pearson \& Rosenberg 1978), fish farming (Tsutsumi 1987. Tsutsumi et al. 1990), waste discharge (Chang et al. 1992) or oil spills (Grassle \& Grassle 1974, Sanders et al. 1980).

\footnotetext{
•E-mail: gamenick@virgil.ruc.dk
}

The population density, reproduction and growth rate of Capitella capitata are strongly correlated with the content of organic material (Tenore 1977, Warren 1977. Chesney \& Tenore 1985, Tenore \& Chesney 1985, Tsutsumi 1987, Grémare et al. 1988, Qian \& Chia 1991, Bridges et al. 1994). The sediments of eutrophicated areas are often anoxic and highly sulfidic due to bacterial degradation of the organic material. Hitherto the dominance of $C$. capitata under such conditions has mainly been explained by its ability to sustain increased mortality rates by continuous reproduction (e.g. Grassle \& Grassle 1974, Pearson \& Rosenberg 1978, Gray 1984). Recently Levin et al. (1996) proposed 
possible demographic mechanisms (e.g. reduced maturation time) which would explain C. capitata's propensity to dominate organically enriched sediments. Little is known, however, about possible ecophysiological adaptations of C. capitata (Gamenick \& Giere 1994, Gamenick et al. 1998) to 2 of the key factors in the benthic environment (Vismann 1991, Giere 1992), oxygen depletion and sulfide accumulation. In many other polychaetes ecophysiological adaptations to hypoxic and sulfidic conditions have been described. Their major adaptation strategies are a high capacity for long-term anaerobiosis (Theede et al. 1969, Theede 1973) and/or the ability to oxidize (= detoxify) sulfide to thiosulfate (Vismann 1991, Bagarinao 1992, Grieshaber \& Völkel 1998).

Capitella capitata consists of a complex of several sibling species which show minor differences in adult morphology, but differ markedly in their reproduction modes and enzyme patterns (Grassle \& Grassle 1976). Moreover, Eckelbarger \& Grassle $(1983,1987)$ described differences in the ultrastructure of eggs and follicle cells, in genital setae, sperm and larval morphology between. sympatric sibling species from the North American East Coast. Several C. Capitata populations, which differ in enzyme patterns ( $W u$ et al. 1991) and reproduction modes (Zhang \& Wu 1988, Pearson \& Pearson 1991) as well as in tolerance to hypoxia and sulfide and standard respiration rates (Gamenick \& Giere 1994), have been described from China, Great Britain and Germany.

In this study, 4 sibling species of Capitella capitata from 3 geographic regions with different sulfide regimes are studied. Former studies revealed that they do not cross breed and are distinguishable by total protein pattern analysis (Gamenick et al. 1998). Two sibling species inhabit the intertidal zone of the North Sea near the island of Sylt, Germany: the small C. capitata Type S (hereafter termed Capitella sp. S) and the large C. capitata Type L (hereafter termed Capitella sp. L) (Gamenick \& Giere 1994). The third sibling species is Capitella sp. M from the Mediterranean Sea near the Island of Milos, where it lives in highly sulfidic sediments close to shallow water hydrothermal vents (Thiermann et al. 1997). It is characterized by high survival rates under anoxic and sulfidic conditions (Gamenick et al. 1998). The fourth sibling species is the well-known Capitella sp. I from eutrophicated sediments of the US East Coast (Grassle \& Grassle $1974,1976)$, which dominates sulfidic sediments near sewage outfalls (J. P. Grassle pers. comm.).

The sibling species were in situ exposed to different oxic and sulfidic conditions and we addressed the following questions: Do the Capitella sibling species have different survival rates under anoxia and sulfide exposure? How do hypoxia, anoxia and sulfide affect their aerobic and anaerobic metabolism? Are there geneti- cally fixed ecophysiological differences between these Capitella sibling species?

To answer these questions, tolerance to hypoxia and sulfide and respiration rates were measured in laboratory-cultured worms under different oxygen and sulfide concentrations. In addition succinate (as an indicator for anaerobic metabolism; Grieshaber et al. 1988), sulfide and thiosulfate concentrations in the worms tissue were analyzed after exposure to different oxygen and sulfide levels.

\section{MATERIAL AND METHOD}

Field. The depth distribution of the 2 sympatric Capitella sp. S and Capitella sp. L was measured in sediment cores taken with plexiglass tubes (inner diameter $5 \mathrm{~cm}, \mathrm{n}=3$ ) and subdivided into $0-3,3-6$ and $6-9 \mathrm{~cm}$ horizons. Samples were fixed in buffered formaldehyde (final concentration 5 to 10 vol. \%), sieved ( $250 \mu \mathrm{m}$ mesh size) and the worms counted. Pore water sulfide concentrations were analyzed photometrically using the colorimetric method of Gilboa-Garber (1971), modified by Howarth et al. (1983). The term sulfide refers here to total dissolved sulfide, i.e. undissociated $\mathrm{H}_{2} \mathrm{~S}$, dissociated $\mathrm{HS}^{-}$and $\mathrm{S}^{2-}$.

Laboratory. All experiments were conducted on laboratory-cultured worms. Stock cultures of Capitella sp. S, Capitella sp. L, Capitella sp. M and Capitella sp. I were reared in aerated glass tanks with sediment (no detectable sulfide) and 32 to $35 \%$ artificial seawater at $18^{\circ} \mathrm{C}$. Worms were fed once a week with commercial fish food mixed with dried green algae.

Tolerance experiments. Capitella sp. S, Capitella sp. L and Capitella sp. I were exposed to 4 treatments (for further descriptions see Gamenick et al. 1998) in artificial seawater $(32$ to $35 \%$ S, for $\mathrm{pH}$ stability buffered with $10 \mathrm{mM}$ HEPES, without sediment) at $16^{\circ} \mathrm{C}$ : (1) normoxia (control), aerated continuously; (2) anoxia, percolated with pure nitrogen prior to inserting the worms; (3) anoxia plus $160 \mu \mathrm{M}$ sulfide; and (4) anoxia plus $760 \mu \mathrm{M}$ sulfide, bubbled with nitrogen with subsequent addition of a sulfide stock solution (made from $\mathrm{Na}_{2} \mathrm{~S}$ $9 \mathrm{H}_{2} \mathrm{O}$ crystals).

Oxygen concentrations were measured with a sulfide-insensitive polarographic oxygen sensor (POS) from Orbisphere (Geneva, Switzerland); $\mathrm{pH}$ was measured with an Ingold electrode (Steinbach/Taunus, Germany) and sulfide concentrations were analyzed colorimetrically as described above. Experimental conditions of the sulfide treatments are given in Table 1.

The term 'normoxia' is defined as $100 \%$ air saturation (oxygen partial pressure, $\mathrm{pO}_{2}=21 \mathrm{kPa}$ ); the term 'anoxia' is used when oxygen concentration is below the POS detection limit $(=0.08 \mathrm{kPa})$. 
Table 1. Experimental conditions of the tolerance tests. Sulfide and pH values were measured at the beginning and at the end of each experiment $(n=6$ to 8$)$

\begin{tabular}{|lcccccc|}
\hline Capitella & $\begin{array}{c}\text { Worms/ } \\
\text { treatment }\end{array}$ & $\begin{array}{c}\text { Number of } \\
\text { experiments }\end{array}$ & $\begin{array}{c}\text { Anoxia }+160 \mu \mathrm{M} \text { sulfide } \\
\text { SH valfide }\left(\mu \mathrm{mol} \mathrm{l^{-1 }}\right)\end{array}$ & \multicolumn{2}{c|}{$\begin{array}{c}\text { Anoxia }+760 \mu \mathrm{M} \text { sulfide } \\
\text { SH valfide }\left(\mu \mathrm{mol} \mathrm{I}^{-1}\right)\end{array}$} \\
\hline sp. S & 6 & 4 & $150 \pm 30$ & $8.13 \pm 0.3$ & $760 \pm 46$ & $8.31 \pm 0.3$ \\
sp. L & 4 & 4 & $150 \pm 30$ & $8.13 \pm 0.3$ & $760 \pm 46$ & $8.26 \pm 0.4$ \\
sp. I & 6 & 3 & $170 \pm 15$ & $8.35 \pm 0.5$ & $775 \pm 36$ \\
\hline
\end{tabular}

Respiration rate experiments. Oxygen consumption (= respiration rate) of the worms at different oxygen levels and sulfide concentrations was measured in a flow-through respirometer set-up (Fig 1).

Experimental set-up: The incubation medium was pumped with a peristaltic pump from 2 bottles, one containing seawater (buffered with $10 \mathrm{mmol}^{-1}$ HEPES, $\mathrm{pH} 7.9$ ), the other a sulfide stock solution ( 400 to $600 \mathrm{umol}$ $\mathrm{l}^{-1}, \mathrm{pH}$ 7.89). Oxygen concentrations were controlled by a gas-mixing pump (Woesthoff, Bochum, Germany). The medium was driven through a mixing chamber $(1 \mathrm{ml}$; flow rate $27 \mathrm{ml} \mathrm{h}^{-1}$ ) into the flow-through system (made of glass) with 2 POS mounted before and behind a flexible animal chamber and a $\mathrm{pH}$ electrode near the outflow. The POS were connected to a 2 channel oxygen meter (Cyclobios, Innsbruck, Austria) equipped with a 2 channel recorder. The flow-through unit was inserted in a $40 \mathrm{l}$ water bath with controlled temperature.

Experimental procedure: Each experimental run was composed of an electrode calibration phase (air = normoxia, nitrogen = anoxia, 10 to $12 \mathrm{~h})$, a respiration measuring phase with worms ( 3 to $4 \mathrm{~h}$ ) under normoxic conditions ( = standard respiration rate), a blank rate measuring phase without worms ( $2 \mathrm{~h})$, and subsequently a second respiration measuring phase at different oxygen (and sulfide) conditions. The run was concluded by a second blank rate measuring phase at same conditions (i.e. sulfide).

The worms were sieved out of the culture several hours prior to the experiments and placed in petri dishes without sediment for clearance of their gut contents. For each experimental run 2 to 15 worms (depending on size) were taken and inserted into the animal chamber. After the 2 respiration measuring phases the wet weight of the worms was determined. In experiments with sulfide, the sulfide concentrations were determined at the beginning and at the end of each second respiration measurement phase using the colorimetric method described above. Oxygen consumption rates of all 4 Capitella sibling species were measured at oxygen tensions of $21,19,17,15,13,11,8,6,4,2$ and $0.4 \mathrm{kPa}$.

Oxygen consumption of the 2 North Sea species Capitella sp. S and Capitella sp. L was measured at 13 , $11,10,9,8,7,6,5,4,3$ and $2 \mathrm{kPa}$ with $100 \mu \mathrm{mol} \mathrm{l}^{-1}$ sulfide $\left(100 \pm 30 \mu \mathrm{mol} \mathrm{l}^{-1}, \mathrm{n}=15\right)$, and at 7 and $11 \mathrm{kPa}$ with different sulfide concentrations between 10 and $140 \mu \mathrm{mol} \mathrm{l}^{-1}$. Oxygen consumption was not measured at normoxia plus sulfide due to technical limitations of the respirometer. During measurements the $\mathrm{pO}_{2}$ variation was about $0.02 \mathrm{kPa}$ and sulfide decreased usually less than $10 \%$.

Incubation experiments. Worms were exposed to different $\mathrm{pO}_{2}$ and sulfide concentrations in a closed incubation chamber (Fig. 2). After exposure, tissue succinate, sulfide and thiosulfate concentrations were analyzed.

In the chamber, oxygen was measured with a sulfide-insensitive POS (Radiometer, Copenhagen, Denmark) modified after Revsbech \& Ward (1983) and connected to a PHM $73 \mathrm{pH} /$ oxygen meter (Radiometer) using a calomel electrode (Radiometer) as reference. pH was measured with a combination electrode (Radiometer) connected to the PHM 73 and sulfide was determined with an $\mathrm{Ag}-\mathrm{Ag}_{2} \mathrm{~S}$ electrode (Vismann 1996) connected to an Ion analyzer (lon 85, Radiometer) using a calomel electrode as reference.

Experimental set-up: The incubation chamber (1 l) was filled with artificial seawater $\left(32 \% \mathrm{~S}, 16^{\circ} \mathrm{C}\right)$, and

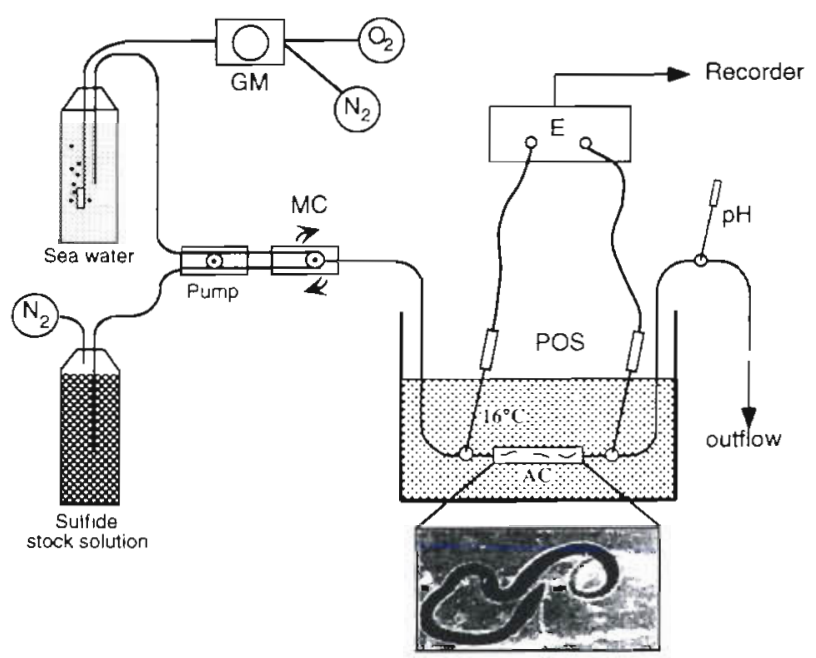

Fig. 1 Schematic view of the flow-through respirometer setup connected to different medium bottles and mixing chamber (MC) for respiration rate measurements at different $\mathrm{pO}_{2}$ and sulfide concentrations. $\mathrm{AC}=$ animal chamber, $\mathrm{E}=$ electronic unit, $\mathrm{GM}=$ gas mixing pump, $\mathrm{pH}=\mathrm{pH}$ electrode, $\mathrm{POS}=$ polarographic oxygen sensors 


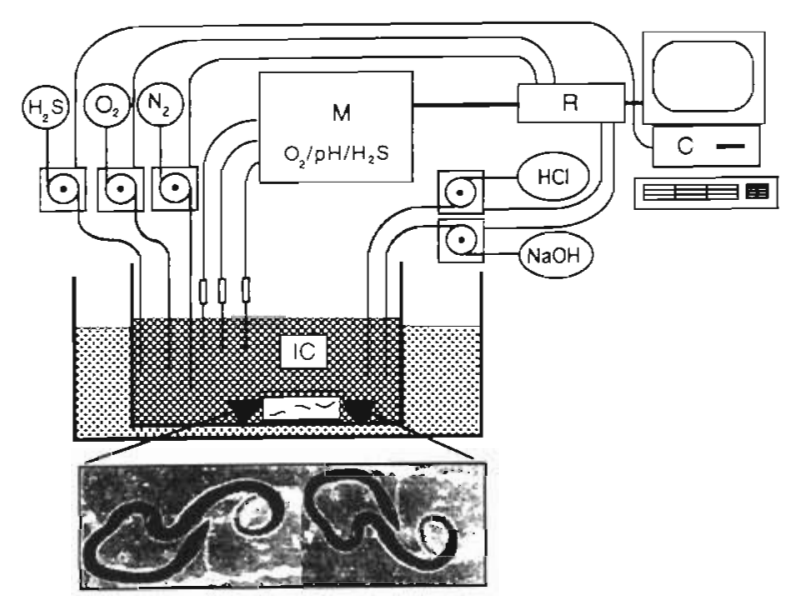

Fig. 2. Schematic view of the computer-controlled incubation set-up. $C$ = calculating section, $\mathrm{IC}=$ incubation chamber, $\mathrm{M}=$ monitoring section, $R$ = regulating section

$\mathrm{pH}$, oxygen and sulfide concentrations were continuously controlled by a computer (for further details see Vismann 1996).

Experimental procedure: Worms were placed in $20 \mathrm{ml}$ vials covered with gauze $(150 \mu \mathrm{m})$. For each sibling species 15 to 30 specimens were incubated in 3 vials (i.e. 5 to 10 specimens per vial). The worms were exposed for $12 \mathrm{~h}$ to different treatments (Table 2) and for $24 \mathrm{~h}$ to anoxia.

Succinate determination: At the end of each exposure the worms were removed from the incubation medium, quickly rinsed with demineralized water, blotted on a paper towel, weighed and frozen at $-80^{\circ} \mathrm{C}$. The frozen samples were homogenized in a $1 \mathrm{ml}$ glass microhomogenizer (Jencons, Bedfordshire, England)

Table 2. Experimental conditions of the computer-controlled incubations for succinate and thiole (") determinations. $\mu \mathrm{M}=$ umol $l^{-1}$ Data acquired every minute $(n=720)$

\begin{tabular}{|c|c|c|c|}
\hline Treatment & $\mathrm{pO}_{2}(\mathrm{kPa})$ & 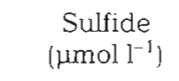 & $\mathrm{pH}$ value \\
\hline Normoxia & $21.5 \pm 0.2$ & - & $7.90 \pm 0.10$ \\
\hline $17 \mathrm{kPa}$ & $17.1 \pm 0.4$ & - & $7.51 \pm 0.09$ \\
\hline $8 \mathrm{kPa}$ & $8.2+0.2$ & - & $7.72 \pm 0.10$ \\
\hline Hypoxia & $0.5 \pm 0.2$ & - & $7.56 \pm 0.08$ \\
\hline Anoxia & $0 \pm 0$ & - & $7.60 \pm 0.09$ \\
\hline $8 \mathrm{kPa}+20 \mu \mathrm{M}$ sulfide & $8.3 \pm 0.4$ & $18.6 \pm 1.2$ & $7.50 \pm 0.01$ \\
\hline Hypoxia $+20 \mu \mathrm{M}$ sulfide & $0.5 \pm 0.1$ & $20.1 \pm 1.2$ & $7.50 \pm 0.01$ \\
\hline Anoxia $+20 \mu \mathrm{M}$ sulfide & $0.0 \pm 0.1$ & $19.7 \pm 1.7$ & $7.51 \pm 0.01$ \\
\hline $8 \mathrm{kPa}+100 \mu \mathrm{M}$ sulfide & $7.8 \pm 0.2$ & $106.4 \pm 15.5$ & $7.51 \pm 0.01$ \\
\hline Hypoxia + $100 \mu \mathrm{M}$ sulfide & $0.5 \pm 0.2$ & $103.8 \pm 7.3$ & $7.51 \pm 0.01$ \\
\hline Anoxia $+100 \mu \mathrm{M}$ sulfide & $0.0 \pm 0.1$ & $1.13 .4 \pm 15.0$ & $7.51 \pm 0.01$ \\
\hline - Normoxia & $21.5 \pm 0.2$ & - & $7.90 \pm 0.10$ \\
\hline $8 \mathrm{kPa}+100 \mu \mathrm{M}$ sulfide & $7.8 \pm 1.1$ & $104.4 \pm 13.5$ & $7.51 \pm 0.01$ \\
\hline - Hypoxia $+100 \mu \mathrm{M}$ sulfide & le $0 \pm 0$ & $111.1 \pm 3.3$ & $7.51 \pm 0.01$ \\
\hline
\end{tabular}

on ice with $150 \mu \mathrm{l}$ of $0.6 \mathrm{~N}$ perchloric acid. The homogenate was centrifuged $(14000 \times g)$ for $15 \mathrm{~min}$ at $15^{\circ} \mathrm{C}$ and the supernatant neutralized in an ice bath with $5 \mathrm{~N} \mathrm{KOH}$. The precipitated potassium perchlorate was again centrifuged and the supernatant frozen at $-20^{\circ} \mathrm{C}$ for storage. Succinate was determined photometrically according to the enzymatic method of Beutler (1985). We used succinate and not lactate or opines as an indicator of anaerobiosis since it has been shown to be a sensitive indicator of mitochondrial anaerobic metabolism in other polychaetes, e.g. Arenicola marina (Schöttler et al. 1984, Völkel \& Grieshaber 1992) and Hediste (Nereis) diversicolor (Schöttler et al. 1984), and in the oligochaete Tubificoides benedii, which is of comparable body size (Dubilier et al. 1994).

Determination of reduced sulfur compounds: Sulfide and thiosulfate concentrations in the worms tissue were measured with the HPLC method (modified by Fahey \& Newton 1987). Monobromobimane (mBBr) (Calbiochem, Giessen, Germany) forms fluorescent adducts with thiols such as sulfide and thiosulfate, which can be separated by reversed-phase HPLC.

At the end of each exposure the worms were removed from the incubation medium, quickly rinsed, blotted, weighed and homogenized on ice in $75 \mu \mathrm{l}$ buffer (50 $\mathrm{mmol} \mathrm{l}^{-1}$ HEPES, $5 \mathrm{mmol} \mathrm{l}^{-1}$ EDTA, pH 8.0) with $75 \mu \mathrm{l}$ acetonitrile and $10 \mu \mathrm{mBBr}\left(48 \mathrm{mmol} \mathrm{l}^{-1}\right)$. The samples were incubated in darkness for $15 \mathrm{~min}$ at room temperature and derivatization was stopped by adding $100 \mu \mathrm{l}$ methane sulfonic acid $\left(65 \mathrm{mmol} \mathrm{l}^{-1}\right)$. The homogenate was stored at $-80^{\circ} \mathrm{C}$.

Chromatography was carried out at room temperature with a Merck/Hitachi HPLC-System (L-6200 Intelligent Pump with LC Organizer; Merck, Darmstadt, Germany/Hitachi, Tokyo, Japan) using a reversedphase column (LiChroSpher 60, RP-select, Merck). The HPLC system was connected to a C-R1 A chromatopac integrator (Shimadzu, Tokyo), allowing online recordings and peak area calculations.

Statistical analysis. Results are given as mean values $(x)$ with their standard deviation (SD). Statistical analysis was carried out on median survival time, respiration rates, succinate and thiole concentrations using the nonparametric $U$-test of Wilcoxon, Mann and Whitney (Sachs 1984). Data are considered as significantly different when $\mathrm{p} \leq 0.05$

\section{RESULTS}

Field

In the North Sea intertidal zone the vertical distribution of Capitella sp. S was markedly different from that of the large Capitella sp. L (Fig. 3). From 95 to $100 \%$ of the 
small Capitella sp. S occurred in the upper 0 to $3 \mathrm{~cm}$ of the sediment where sulfide concentrations never exceeded $20 \mathrm{umol} \mathrm{l}^{-1}$, whereas 67 to $100 \%$ of Capitella sp. L. were found in the deeper sediment layers $(3$ to $9 \mathrm{~cm}$ ) with anoxia and sulfide concentrations of up to $350 \mu \mathrm{mol} \mathrm{l}^{-1}$.

\section{Laboratory}

For comparison, morphological features (see Grassle \& Grassle 1974) and life history in the 4 laboratory-cultured sibling species of Capitella are given in Table 3. Capitella sp. S from the North Sea was the smallest sibling species, never exceeding a body length of $1.5 \mathrm{~cm}$, whereas adults of Capitella sp. L could grow in culture up to $4.5 \mathrm{~cm}$ body length. No other differences in morphology among the 4 species were found in the present study. Differences in brood sizes and reproductive modes were, however, remarkable. Capitella sp. S was the only species producing benthic juvenile larvae, while the 3 other species had free-swimming trochophore larvae.

\section{Tolerance to anoxia and sulfide}

Comparison of the Capitella sibling species in survival rates under anoxia and anoxia plus high sulfide reveals species-specific differences (Fig. $4 \mathrm{a}-\mathrm{c}$ ). At anoxia and at anoxia plus sulfide the median survival times of Capitella sp. S ( $\mathrm{LT}_{50}$, high sulfide: $28 \pm 11 \mathrm{~h}$, $\mathrm{n}=4$ ) were significantly shorter than median survival times of Capitella sp. L (LT $\mathrm{L}_{50}$, high sulfide: $47 \pm 6 \mathrm{~h}, \mathrm{n}=$ 4) and Capitella sp. I ( $\mathrm{LT}_{50}$, high sulfide: $65 \pm 6 \mathrm{~h}, \mathrm{n}=3$ ), which was the most tolerant sibling species.
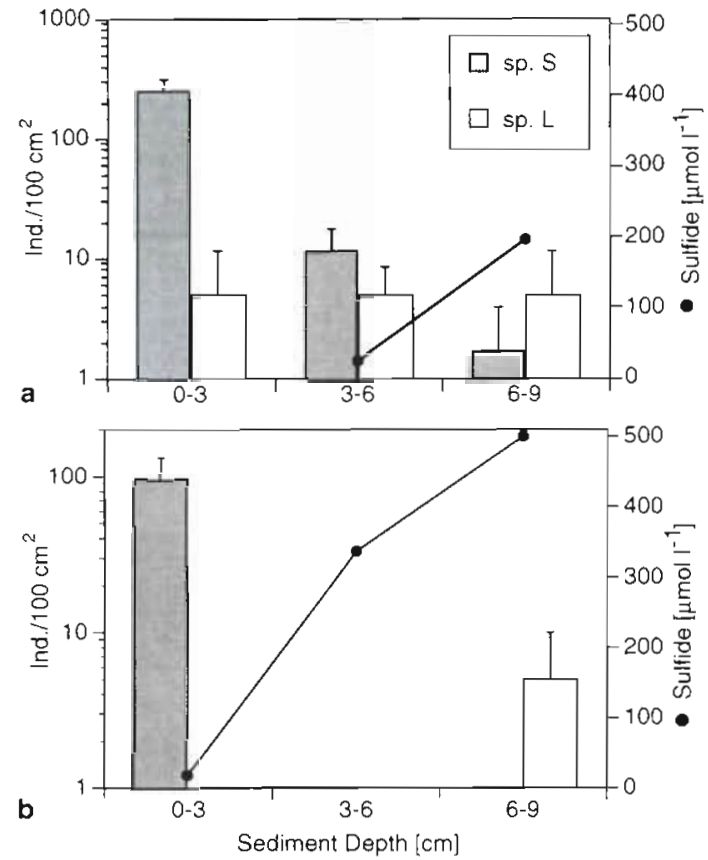

Fig. 3. Mean vertical distribution $(n=3)$ of Capitella sp. S and Capitella $\mathrm{sp}$. L compared to pore water sulfide concentrations

in (a) June and (b) August 1991 in the intertidal zone of the island of Sylt (North Sea). Note logarithmic scale

\section{Oxygen consumption}

The standard respiration rates of the 4 Capitella sibling species at normoxia (21.0 kPa) are given in Table 4 and used as the $100 \%$ value in Fig. 5.

In Capitella sp. S the oxygen consumption became successively reduced with declining ambient oxygen tensions (Fig. 5). At high oxic levels (19.1 kPa and $16.8 \mathrm{kPa}$ ) the standard respiration rate of $11.95 \pm$

Table 3. Morphological features and life history in 4 Capitella sibling species. nm: not measured

\begin{tabular}{|c|c|c|c|c|}
\hline $\begin{array}{l}\text { Capitella: } \\
\text { Geogr, region: } \\
\text { Sulfide }\left(\mu \mathrm{mol} \mathrm{l}^{-1}\right) \text { : }\end{array}$ & $\begin{array}{c}\text { sp. S } \\
\text { Sylt, Germany } \\
20\end{array}$ & $\begin{array}{c}\text { sp. L } \\
\text { Sylt, Germany } \\
350\end{array}$ & $\begin{array}{c}\text { sp. Mrt } \\
\text { Milos, Greece } \\
710\end{array}$ & $\begin{array}{c}\text { sp. I } \\
\text { Woods Hole, USA } \\
\text { High (nm) }\end{array}$ \\
\hline \multicolumn{5}{|c|}{ Adult morphology (from cultures) } \\
\hline Body length (mm) & $6-15$ & $25-45$ & $15-25$ & $15-20$ \\
\hline Wet weight $(\mathrm{mg})$ & $0.3-2.5$ & $3.2-12$ & $3.6-9.2$ & $3-12^{b}$ \\
\hline Sex & Monoecious & Monoecious & Mon-/dioecious & Mon-/dioecious \\
\hline Prostomium & Broad triangular & Broad triangular & Broad triangular & Broad triangular \\
\hline $\begin{array}{l}\text { Setae (teeth) } \\
\text { (Row and formula) }\end{array}$ & $\begin{array}{c}\text { Present } \\
(1 / 4)\end{array}$ & $\begin{array}{c}\text { Present } \\
(1 / 4)\end{array}$ & $\begin{array}{c}\text { Present } \\
(1 / 4)\end{array}$ & $\begin{array}{c}\text { Present } \\
(1-3 / 3-5)^{b}\end{array}$ \\
\hline \multicolumn{5}{|l|}{ Eggs } \\
\hline Number & $30-50$ & $>70$ & $100-300$ & $30-400^{b}$ \\
\hline Diameter ( $\mu \mathrm{m})$ & $240-250$ & $170-180$ & $228 \pm 10(\mathrm{n}=30)$ & $260 \times 180^{b}$ \\
\hline \multicolumn{5}{|l|}{ Larvae } \\
\hline Length $(\mu \mathrm{m})$ & $1047 \pm 178(n=16)$ & $328 \pm 55(n=24)$ & $456 \pm 8(n=30)$ & $210^{r}$ \\
\hline Larval mode & Benthic & Lecithotrophic & Lecithotrophic & Lecithotrophic \\
\hline Free-swimming & - & Several hours & Several hours & Several hours \\
\hline
\end{tabular}



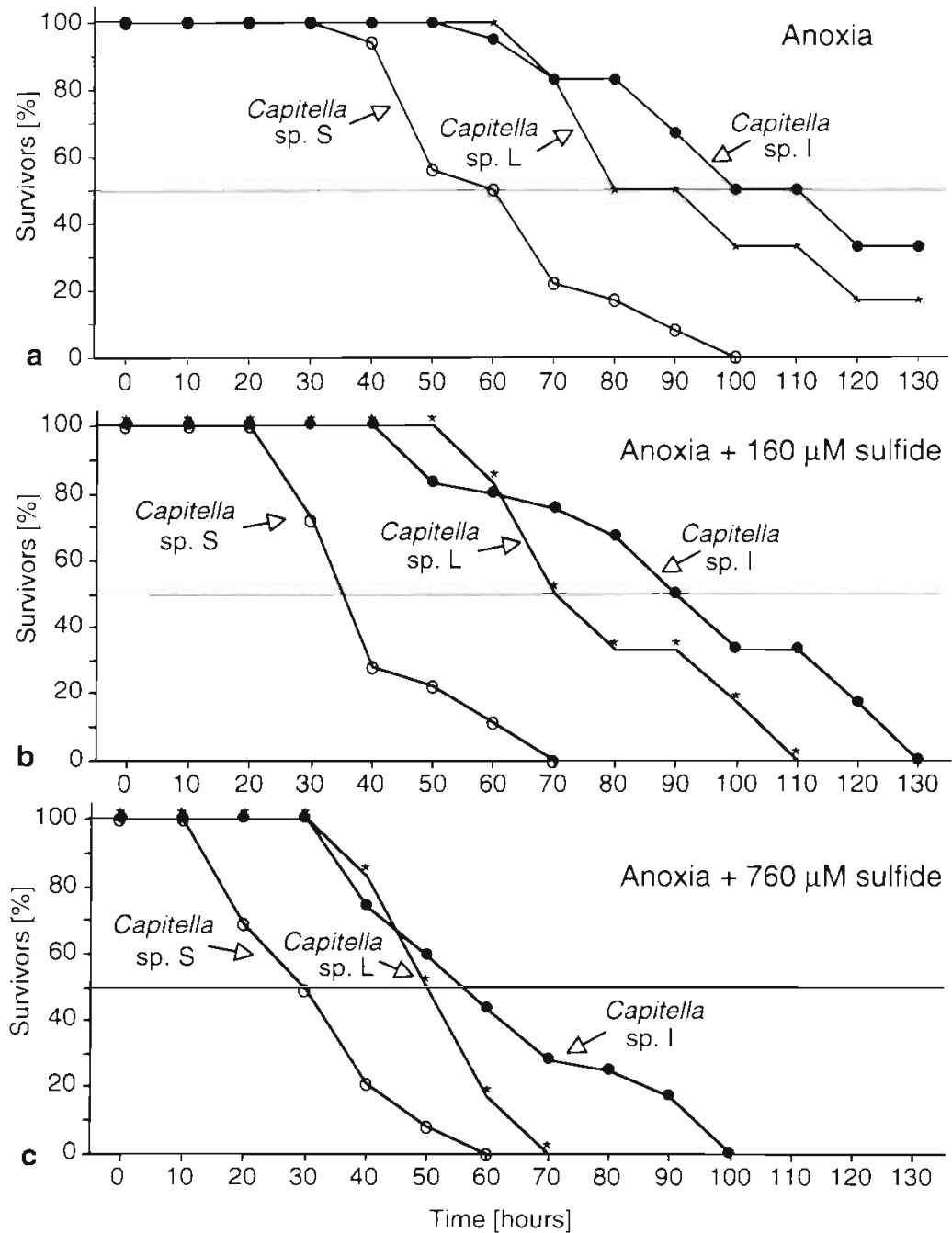

Fig. 4. Average survival rates of Capitella sp. S (0), Capitella sp. L (*) and Capitella sp. I ( ) under (a) anoxia, (b) anoxia plus $160 \mu \mathrm{mol} \mathrm{I} \mathrm{I}^{-1}$ sulfide and (c) anoxia plus $760 \mu \mathrm{mol}^{-1}$ sulfide as a function of time. Standard deviations (9 to $29 \%$ ) are not shown

At constant oxygen tensions of $11 \mathrm{kPa}$ the presence of more than $70 \mu \mathrm{mol} \mathrm{l^{-1 }}$ sulfide reduced the oxygen consumption of Capitella sp. S (Fig. 6). At $7 \mathrm{kPa}$ the oxygen consumption was significantly reduced at $30 \mu \mathrm{mol} \mathrm{l}^{-1}$ sulfide. This con.trasts to results for Capitella sp. L, where at 11 and $7 \mathrm{kPa}$ sulfide concentrations of up to 130 and $100 \mathrm{~mol} \mathrm{l}^{-1}$ respectively had no effect on the oxygen consumption.

\section{Succinate content in the tissues}

In all Capitella sibling species internal succinate concentrations increased with decreasing ambient oxygen tensions and reached maximum values at anoxic conditions (Fig. 7).

In Capitella sp. S succinate concentrations increased significantly in the presence of 20 and $100 \mu \mathrm{mol} \mathrm{l} \mathrm{l}^{-1}$ sulfide at $8.42 \mathrm{kPa}$. In contrast, in Capitella sp. L the presence of $20 \mu \mathrm{mol} \mathrm{l}^{-1}$ sulfide had no effect on succinate levels, but $100 \mu \mathrm{mol} \mathrm{l}^{-1}$ sulfide led to increased succinate content in the worm. In Capitella sp. $M$ neither 20 nor $100 \mu \mathrm{mol} \mathrm{l} \mathrm{l}^{-1}$ sulfide was sufficient to cause an increase in succinate levels. In Capitella sp. I at $8.42 \mathrm{kPa}$ the presence of $20 \mathrm{~mol} \mathrm{1^{-1 }}$ sulfide also had no effect, but at hypoxia $(0.4 \mathrm{kPa}) 100 \mu \mathrm{mol} \mathrm{l^{-1 }}$ sulfide led to increased succinate concentrations in this sibling species.

\section{Sulfide and thiostilfate}

$1.86 \mu \mathrm{mol} \mathrm{O} \mathrm{h}^{-1} \mathrm{~g}^{-1}$ wwt was significantly reduced by $10 \pm 4$ and $22 \pm 6 \%$ respectively. At $9.5 \mathrm{kPa}$, the presence of $100 \mu \mathrm{mol} \mathrm{l}^{-1}$ sulfide caused a significant $78 \%$ reduction of oxygen consumption.

In Capitella sp. L the oxygen consumption decreased below ambient oxygen tensions of $16.8 \mathrm{kPa}$. The presence of $100 \mathrm{mmol} \mathrm{l}^{-1}$ sulfide led to a slight decrease of respiration. In contrast to Capitella sp. S, Capitella sp. L was able to maintain its oxygen consumption between 12.6 and $6.3 \mathrm{kPa}$ at a stable level. Capitella sp. M maintained a high oxygen consumption $(70 \pm 12 \%$ of the standard respiration rate of $7.74 \pm 1.86 \mu \mathrm{mol} \mathrm{O}_{2} \mathrm{~h}^{-1} \mathrm{~g}^{-1}$ wwt) down to oxygen tensions as low as $2.1 \mathrm{kPa}$. Capitella sp. I maintained its oxygen consumption at a stable level at higher oxygen tensions. A significant decrease was measured below ambient oxygen tensions of $8.42 \mathrm{kPa}$.
Hypoxia $(0.4 \mathrm{kPa})$ plus $100 \mu \mathrm{mol} \mathrm{l}^{-1}$ ambient sulfide concentrations produced an increase in internal sulfide concentrations in all 4 Capitella species, compared to non-sulfidic conditions (Table 5). The presence of

Table 4. Average standard respiration rates of 4 Capitella sibling species under normoxic conditions. n: number of experimental runs

\begin{tabular}{|lc|}
\hline Capitella & $\dot{\mathrm{M} \mathrm{O}} 2\left(\mu \mathrm{mol} \mathrm{h} \mathrm{h}^{-1} \mathrm{~g}^{-1}\right.$ wet wt) \\
\hline sp. S & $11.95 \pm 1.86(\mathrm{n}=19)$ \\
sp. L & $5.78 \pm 1.16(\mathrm{n}=14)$ \\
sp. M & $7.74 \pm 1.86(\mathrm{n}=18)$ \\
sp. I & $9.23 \pm 1.58(\mathrm{n}=10)$ \\
\hline
\end{tabular}




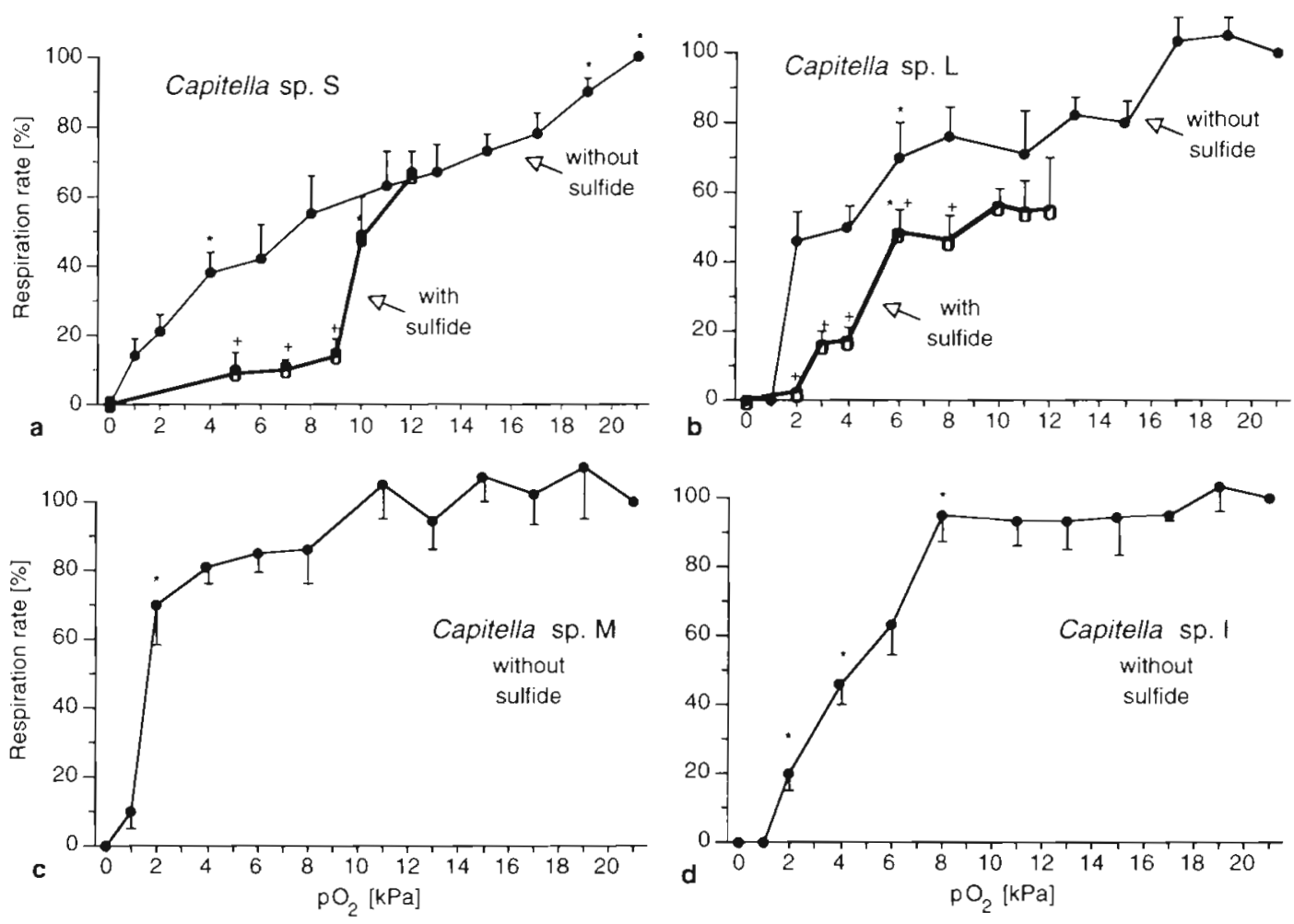

Fig. 5. Standard respiration rate $(=100 \%$, compare Table 4$)$ and mean $\mathrm{pO}_{2}$-dependent oxygen consumption of (a) Capitella sp. S, (b) Capitella sp. L, (c) Capitella sp. M and (d) Capitella sp. I without sulfide (n= 8) and of (a) Capitella sp. S and (b) Capitella sp. $\mathrm{L}$ in the presence of $100 \mathrm{mmol} \mathrm{I}^{-1}$ sulfide $(\mathrm{n}=6)$. "Significantly different from former value (lower $\left.\mathrm{pO}_{2}\right)$. $(+)$ Significantly different from respiration rates without sulfide

$8.4 \mathrm{kPa}$ oxygen at sulfidic conditions led to significantly decreased internal sulfide concentrations compared to hypoxia with sulfide.

Thiosulfate concentrations in all 4 Capitella species increased when exposed to $100 \mathrm{Hmol} \mathrm{I}^{-1}$ sulfide and hypoxia, and the presence of oxygen under sulfidic conditions led to a further significant thiosulfate increase (Table 6).

\section{DISCUSSION}

\section{Tolerance to anoxia and sulfide}

The sibling species of Capitella capitata showed significant differences in their tolerance to anoxia and sulfide. Capitella sp. S from the upper intertidal sediments had the lowest tolerance to anoxia and sulfide, while the sympatric Capitella sp. L from the deeper sulfide-rich sediment layers was more tolerant. A sizedependent tolerance as found in Arenicola marina (Groenendaal 1980) does not exist, since the 'medium sized' Capitella sp. M from hydrothermal areas of Milos is much more tolerant (Gamenick et al. 1998) than the Capitella sibling species from the North Sea and the North Atlantic tested in this study. As described for
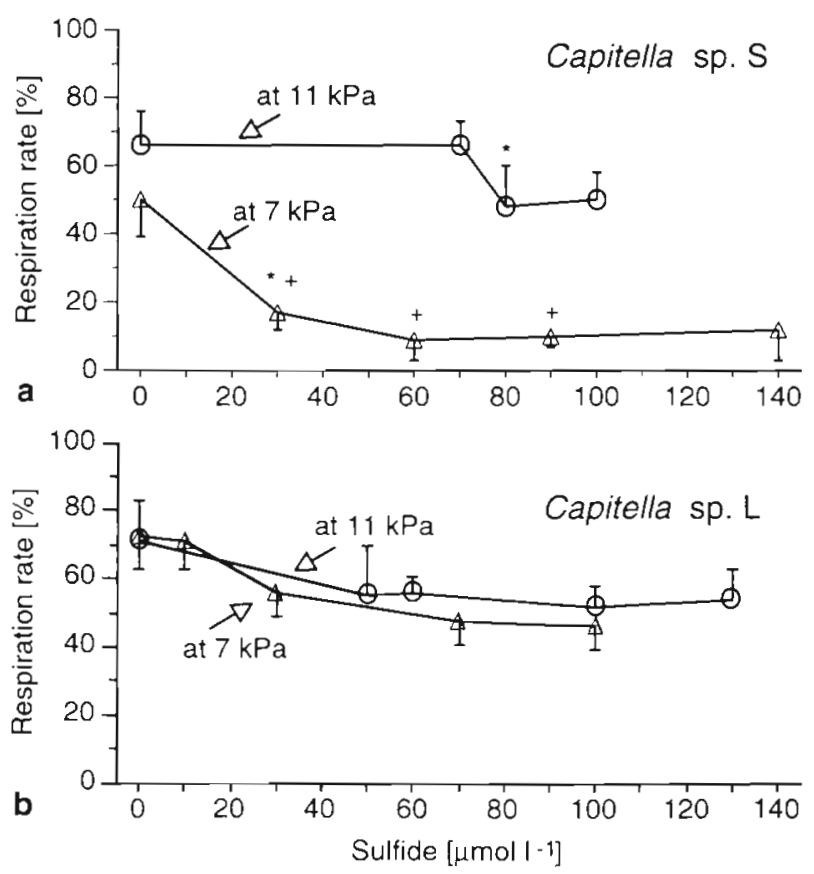

Fig. 6. Mean sulfide-dependent respiration rates of (a) Capitella sp. S and (b) Capitella sp. L at constant oxygen tensions of 11 and $7 \mathrm{kPa}(\mathrm{n}=6)$. "Significantly different from former value (lower sulfide). (+) Significantly different from respiration rates at $11 \mathrm{kPa}$ 

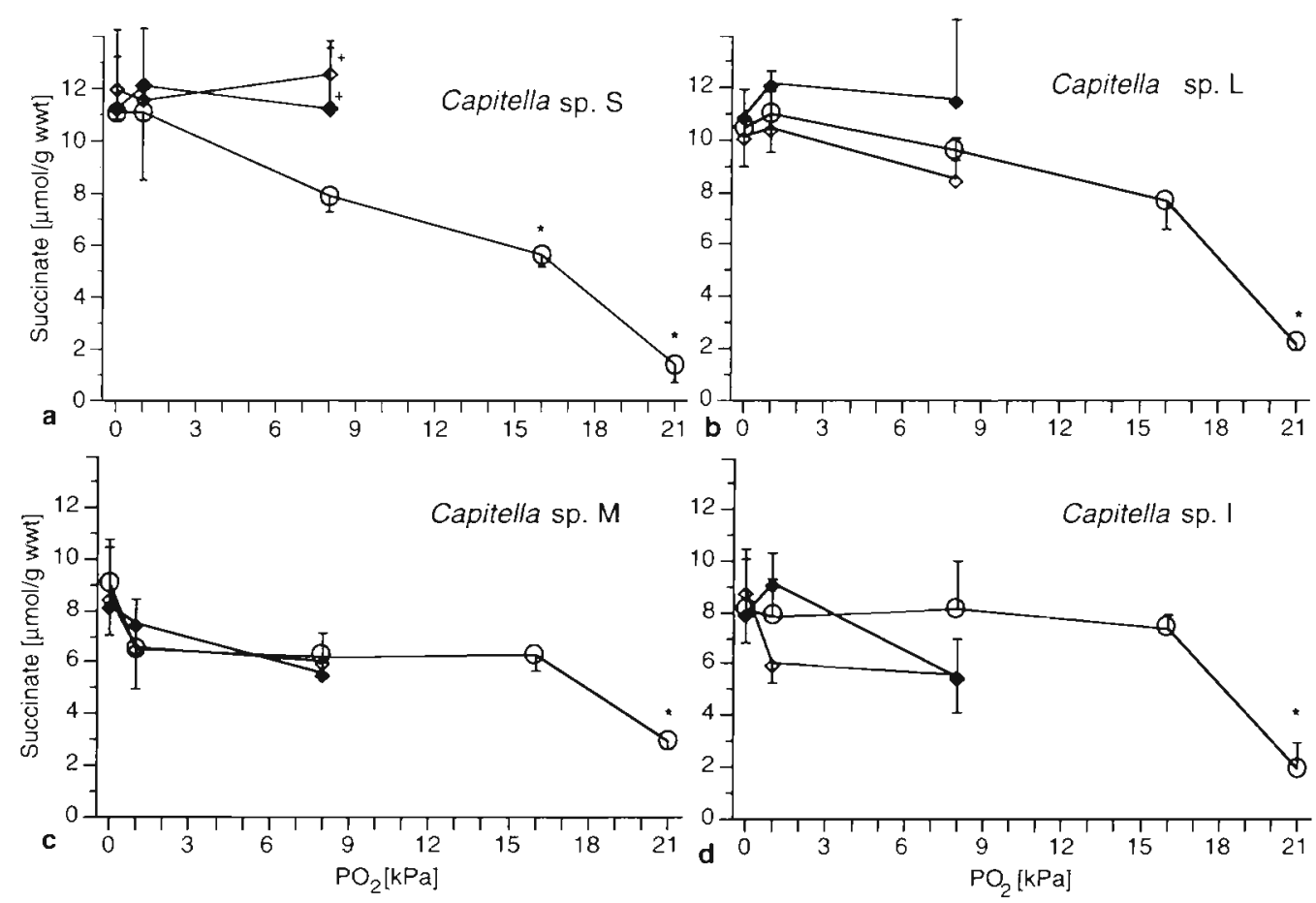

Fig. 7. $\mathrm{pO}_{2}$-dependent internal succinate concentrations $(\mathrm{n}=3$ ) in (a)Capitella sp. $\mathrm{S}$ ( (b) Capitella sp. L, (c) Capitella sp. M and (d) Capitella sp. I after incubations without sulfide $(0)$ and in the presence of $20 \mu \mathrm{mol} \mathrm{l}^{-1}(\diamond)$ and $100 \mu \mathrm{mol} \mathrm{I}^{-1}$ sulfide $(\bullet)$. . Significantly different from former value (lower $\mathrm{pO}_{2}$ ). (+) Significantly different from value without sulfide

different Nereis species, the present study confirms the presence of a close correlation between habitat sulfide exposure and survival capacity (Theede et al. 1973, Vismann 1990). Moreover, in the Baltic clam Macoma balthica different degrees of sulfide tolerance occur even at population levels (Jahn \& Theede 1997). In the present study, the mean tolerance to anoxia varied between 2.2 (Capitella sp. S) and 4.2 d (Capitella sp. I), confirming that an unusually high resistance to low oxygen tensions does not exist for C. capitata (e.g. Warren 1984, Forbes \& Lopez 1990). Other polychaetes, e.g. Nereis (Hediste) diversicolor, Nereis (Neanthes) virens and the lugworm Arenicola marina, all survive anoxia for $5 \mathrm{~d}$ or longer (Theede et al. 1969, Schöttler \& Grieshaber 1988, Gamenick et al. 1996). Sulfide tolerance (anoxia plus $760 \mu \mathrm{mol} \mathrm{l}^{-1}$ sulfide) of

Table 5. Mean ( $\mathrm{n}=3$ ) internal sulfide concentrations $\left(\mathrm{nmol} \mathrm{^{-1 }}\right.$ wwt) of 4 Capitella sibling species at normoxia, at $8.4 \mathrm{kPa} \mathrm{pO}_{2}$ with $100 \mu \mathrm{mol} \mathrm{I}^{-1}$ sulfide and at $0.4 \mathrm{kPa} \mathrm{pO}_{2}$ with $100 \mu \mathrm{mol} \mathrm{l}^{-1}$ sulfide

\begin{tabular}{|lllll|}
\hline Treatment & sp. S & sp. L & sp. M & sp. I \\
\hline Normoxia & $22 \pm 3$ & $24 \pm 3$ & $24 \pm 5$ & $23 \pm 4$ \\
$8 \mathrm{kPa}+$ sulfide & $43 \pm 8$ & $39 \pm 3$ & $16 \pm 9$ & $55 \pm 10$ \\
Hypoxia + sulfide & $68 \pm 11$ & $65 \pm 20$ & $72 \pm 25$ & $60 \pm 15$ \\
\hline
\end{tabular}

the Capitella species, ranging from 1.2 (Capitella sp. S) to $4.4 \mathrm{~d}$ (Capitella sp. M), is also low compared to other polychaete species. For Owenia fusiformis Groenendaal (1980) demonstrated a maximal survival time of 5 d under hypoxia plus $10 \mathrm{mmol}^{-1}$ sulfide.

\section{Effects of oxygen depletion and sulfide on the aerobic metabolism}

The patterns of $\mathrm{pO}_{2}$-dependent respiration rates in response to changes in ambient oxygen tensions differ markedly among the 4 Capitella sibling species. Only the oxygen consumption of Capitella sp. $\mathrm{S}$ becomes successively reduced with declining oxygen tensions. Due to this linear oxygen dependence of its respiration

Table 6. Mean ( $\mathrm{n}=3$ ) internal thiosulfate concentrations (nmol g-1 wwt) of 4 Capitella sibling species at normoxia, at $8.4 \mathrm{kPa} \mathrm{pO}_{2}$ with $100 \mu \mathrm{mol} \mathrm{l}^{-1}$ sulfide and at $0.4 \mathrm{kPa} \mathrm{pO}$ with $100 \mu \mathrm{mo}] \mathrm{I}^{-1}$ sulfide

\begin{tabular}{|lrrrc|}
\hline Treatment & sp. S & sp. L & sp. M & sp. I \\
\hline Normoxia & $16 \pm 4$ & $15 \pm 4$ & $24 \pm 15$ & $18 \pm 5$ \\
$8 \mathrm{kPa}+$ sulfide & $174 \pm 16$ & $188 \pm 17$ & $163 \pm 32$ & $199 \pm 10$ \\
Hypoxia + sulfide & $54 \pm 11$ & $77 \pm 18$ & $74 \pm 22$ & $79 \pm 1$ \\
\hline
\end{tabular}


rate, Capitella sp. S can be characterized as an typical oxyconformer (Prosser 1973). A similar oxyconforming pattern was reported by Warren (1984) for a non specified C. capitata population.

In contrast to Capitella sp. S, the 3 other Capitella sibling species can be characterized as oxyregulators (Prosser 1973). They keep oxygen consumption $\mathrm{pO}_{2}$-independent through increased ventilation over a range of ambient oxygen tensions and switch to oxyconformity below a critical oxygen tension $\left(\mathrm{P}_{\mathrm{cr}}\right)$ (e.g. Herreid 1980, Grieshaber et al. 1994). To be a regulator and thus to keep an energetically more efficient aerobic ATP production as long as possible is of advantage for an organism (e.g. Hochachka \& Somero 1984). However, speciesspecific differences in the regulation ability of the Capitella sibling species were found. According to Herreid (1980), Capitella sp. L can be termed as a bad regulator because of its high $\mathrm{P}_{\mathrm{cr}}(16.8 \mathrm{kPa})$. Capitella sp. I, as a moderate regulator, is able to keep its oxygen consumption $\mathrm{pO}_{2}$-independent above a $\mathrm{P}_{\mathrm{cr}}$ of $7 \mathrm{kPa}$. In contrast, Capitella sp. M has an extremely low $\mathrm{P}_{\mathrm{cr}}$ of $2 \mathrm{kPa}$; it can be termed as a good regulator, well adapted to fluctuating $\mathrm{pO}_{2}$. Capitella sp. M maintains the energetically more efficient aerobic metabolism even at low oxygen. terusions, which is advantageous for the polychaete in the rigid habitat near the hydrothermal vents. The present study underlines once more that the dichotomous distinction between conformers and regulators is oversimplified; many exceptions and several transitions between 'perfect conformity' and 'perfect regulation' are known (Pörtner \& Grieshaber 1993, Grieshaber et al. 1994).

Addition of sulfide leads to a decrease in respiration rate in both investigated North Sea species, due to inhibition of the key enzyme of aerobic respiration, cytochrome coxidase (Somero et al. 1989, Bagarinao \& Vetter 1990, Vismann 1991). However, differences were found between these 2 sympatric species. At declining ambient oxygen tensions the presence of $100 \mu \mathrm{mol} \mathrm{l}^{-1}$ sulfide led to a significant reduction in respiration rate in the sensitive Capitella sp. S, whereas the tolerant Capitella sp. L maintained its oxygen uptake in these conditions. At lower oxygen levels, sulfide concentrations as low as $30 \mu \mathrm{mol} \mathrm{l}^{-1}$ inhibited aerobic pathways of Capitella sp. S. In contrast, the respiration rate of Capitella sp. L was not affected even at higher sulfide concentrations, underlining the adaptation of this sibling species to hypoxia and sulfidic conditions of its environment, the deeper sediments of the Wadden Sea.

\section{Effects of oxygen depletion and sulfide on the anaerobic metabolism}

With declining ambient oxygen tensions, internal succinate concentrations increased in the Capitella sibling species, indicating that decreased respiration rates were related to a successive onset of an anaerobic metabolism, not to reduced activity or ventilation rates. This phenomenon has also been described for other marine invertebrates, e.g. Sipunculus nudus (Pörtner 1982), Arenicola marina (Völkel \& Grieshaber 1992), Hediste diversicolor (Schöttler et al. 1984), Halicryptus spinulosus (Oeschger 1990) and recently also for the small ostracod Cyprideis torosa (Jahn et al. 1996) from shallow sulfidic sediments of the Baltic Sea.

A sulfide-induced onset of anaerobic metabolism could be shown not only by respiration data but also by increased succinate levels in all Capitella sibling species. Differences among the sibling species were found with the North Sea Capitella sp. S being the most sensitive to sulfide. In this species, low sulfide concentrations of $20 \mu \mathrm{mol} \mathrm{l}^{-1}$ led to total anaerobiosis in the presence of moderate ambient oxygen tensions. In the more tolerant Capitella sp. L this could only be shown at sulfide concentrations of $100 \mu \mathrm{mol} \mathrm{l^{-1 }}$. In contrast, the same conditions did not elicit increased anaerobiosis in Capitella sp. M and in Capitella sp. I. In these 2 tolerant species the presence of sulfide only caused an increase in anaerobiosis under hypoxic conditions.

The oxygen-dependent effect of sulfide on the metabolism (inhibition of aerobic pathways and onset of anaerobiosis) shown in this paper for the 4 Capitella species has also been described for other marine invertebrates, e.g. Sipunculus nudus (Völkel \& Grieshaber 1992), Arenicola marina (Völkel \& Grieshaber 1992. Hauschild 1996), the oligochaete Tubificoides benedii (Dubilier et al. 1994) and thalassinidean crustacea (Johns et al. 1997). Sulfide induced anaerobiosis in these species, even at normoxic conditions, and at lower ambient oxygen tensions much less sulfide was needed to give the same effect. Sulfide-dependent anaerobiosis has been discussed as being an adaptation to sulfidic habitats (Grieshaber et al 1992, Oeschger \& Vetter 1992). Comparing different marine invertebrates (exposed to the same oxygen conditions), very different sulfide concentrations inhibit aerobic metabolism (e.g. Oeschger \& Vetter 1992, Dubilier et al. 1994, Volkel \& Grieshaber 1994). As shown in the 4 Capitella species the defense systems against sulfide toxicity which prevent inhibition of aerobic metabolism are species-specific. Indeed, several comparative studies on marine invertebrates have shown marked differences in the ability to detoxify sulfide (Vetter et al. 1987, Bagarinao \& Vetter 1990, Vismann 1990, Levitt \& Arp 1991, Völkel \& Grieshaber 1992).

The onset of anaerobiosis in Capitella sp. L at oxygen levels of $7 \mathrm{kPa}$ (Fig. $7 \mathrm{~b}$ ), while oxygen consumption is not reduced (Fig. 6b), could indicate that oxygen is used for sulfide oxidation (e.g. Grieshaber \& Völkel 1998) as shown in increased internal thiosulfate levels 
(see below). Thus, in contrast to Capitella sp. S, aerobic metabolism is not inhibited under these conditions. Recently Völkel \& Grieshaber (1996) showed that the sulfide-tolerant lugworm Arenicola marina is able to oxidize sulfide even under high sulfidic conditions via an alternative sulfide-insensitive terminal oxidase. One could discuss that Capitella sp. L might also have such an alternative oxidase to survive sulfidic conditions.

The 4 Capitella species were unable to prevent the diffusion of sulfide into the body but were able to oxidize it to thiosulfate if oxygen was available. This oxidative step has been interpreted as an adaptation in several animals from sulfidic habitats (for reviews see Somero et al. 1989, Vismann 1991, Bagarinao 1992, Grieshaber \& Völkel 1998). The occurrence of internal succinate, sulfide and thiosulfate in all Capitella species in the control at normoxia is probably due to the fact that the worms were kept in culture tanks with sediment. Here, they were exposed to hypoxia and sulfide in deeper sediment layers despite aeration of the tank. To remove the worms from sediment prior to experiments for a longer time period was not possible because of starvation symptoms.

The differentiation of the 4 Capitella sibling species is much more pronounced on an ecophysiological level than on the morphological level, reflecting the degree of 'sulfide stress' experienced in the natural habitat. This is in addition to different general protein patterns (Gamenick et al. 1998) and reproduction modes (see Table 3).

This study demonstrates that genetically fixed ecophysiological differences occur within the Capitella capitata complex. Our results are consistent with the conception that abiotic stress - for example hypoxia and/or sulfide - can be a driving force of genetic differentiation, resulting in physiological divergence. Hence, C. capitata is an ecophysiologically much more diverse species complex than has previously been recognized. Thus, the unreflected and summative use of C. capitata as an indicator species for disturbed and polluted environments must be questioned.

Acknowledgements. We thank Susanne Völkel for her introduction into succinate analysis and HPLC measurements and for valuable discussions. We thank Lars Hagermann and 4 anonymous referees for their constructive criticism on the manuscript. This work was supported by the German Bundesministerium für Bildung, Wissenschaft und Forschung (BMBF) under the project DYSMON (03F0123D) to O.G. and by the Danish Science Research Council No. 11-8391/0088 to B.V.

\section{LITERATURE CITED}

Bagarinao T (1992) Sulfide as an environmental factor and toxicant: tolerance and adaptations in aquatic organisms. Aquat Toxicol 24:21-62
Bagarinao T, Vetter RD (1990) Oxidative detoxification of sulfide by mitochondria of the California killifish Fundulus parvipinnis and the speckled sanddab Citharichtys stigmaeus. J Comp Phys [B] 169:519-527

Beutler HO (1985) Succinat. In: Bergmeyer HU (ed) Methods of enzymatic analysis. Verlag Chemie, Weinheim, p 25-33

Bridges TS, Levin LA, Cabrera D, Plaia G (1994) Effects of sediment amended with sewage, algae, or hydrocarbons on growth and reproduction in two opportunistic polychaetes. J Exp Mar Biol Ecol 177:99-119

Chang S, Steimle FW, Reid RN, Fromm SA, Zdanowicz VS, Pikanowski RA (1992) Association of benthic macrofauna with habitat types and quality in the New York Bight. Mar Ecol Prog Ser 89:251-253

Chesney EJ Jr, Tenore KR (1985) Oscillations of laboratory populations of the polychaete Capitella capitata (Type I): their cause and implications for natural populations. Mar Ecol Prog Ser 20:289-296

Dubilier N, Giere O, Grieshaber MK (1994) Concomitant effect of sulfide and hypoxia on the metabolism of the marine oligochaete Tubificoides benedii. J Exp Zool 269 : $287-297$

Eckelbarger KJ, Grassle JP (1983) Ultrastructural differences in the eggs and ovarian follicle cells of Capitella (Polychaeta) sibling species. Biol Bull 165:379-393

Eckelbarger KJ, Grassle JP (1987) Interspecific variation in genital spine, sperm, and larval morphology in six sibling species of Capitella. Bull Biol Soc Wash 7:62-76

Fahey RC, Newton GL (1987) Determination of low-molecular weight thiols using monobromobimane fluorescent labeling and high performance liquid chromatography. Meth Enzymol 143:85-96

Forbes TL, Lopez GR (1990) The effect of food concentration, body size, and environmental oxygen tension on the growth of the deposit-feeding polychaete, Capitella species I. Limnol Oceanogr 35(7):1535-1544

Gamenick I, Giere O (1994) Population dynamics and ecophysiology of Capitella capitata from North Sea intertidal flats. Evidence for two sibling species. Polychaete Res 16 : $44-47$

Gamenick I, Jahn. A, Vopel K, Giere O (1996) Hypoxia and sulfide as structuring factors in a macrozoobenthic community on the Baltic shore: colonization studies and tolerance experiments. Mar Ecol. Prog Ser 144:73-85

Gamenick I, Abbiati M, Giere O (1998) Field distribution, tolerance and general protein patterns of Capitella capitata (Annelida: Polychaeta) around shallow water hydrothermal vents off Milos (Aegean Sea). Mar Biol 130(3): $447-453$

Giere O (1992) Benthic life in sulfidic zones of the sea (ecological and structural adaptations to a toxic environment. Ver Dtsch Zool Ges 85.2:77-93

Gilboa-Garber N (1971) Direct spectrophotometric determination of inorganic sulfide in biological materials and in other complex mixtures. Analyt Biochem 43:129-133

Grassle JF, Grassle JP (1974) Opportunistic life histories and genetic systems in marine benthic polychaetes. J Mar Res $32: 253-284$

Grassle JF, Grassle JP (1976) Sibling species in the marine pollution indicator Capitella (Polychaeta). Science 192: $567-569$

Gray JS (1.984) Ökologie mariner Sedimente. Eine Einführung. Springer, Berlin

Grémare A, Marsh AG, Tenore KR (1988) Short-term reproductive responses of Capitella sp. I (Annelida, Polychaeta) fed on different diets. J Exp Mar Biol Ecol 123:147-162 
Grieshaber MK, Völkel S (1998) Animal adaptations for tolerance and exploitation of poisonous sulfide. Annu Rev Physiol 60:33-53

Grieshaber MK, Hardewig I, Kreutzer U, Schneider A, Völkel $S$ (1992) Hypoxia and sulfide tolerance in some marine invertebrates. Verh Dtsch Zool Ges 85.2:55-76

Grieshaber MK, Hardewig I, Kreutzer U, Pörtner HO (1994\} Physiological and metabolic responses to hypoxia in invertebrates. Rev Physiol Biochem Pharmakol 125:44-147

Grieshaber MK, Kreutzer U, Pörtner $\mathrm{HO}$ (1988) Critical $\mathrm{PO}_{2}$ of euryoxic animals. In: Acker $\mathrm{H}$ (ed) Oxygen sensing in tissues. Springer, Berlin, p $37-48$

Groenendaal M (1980) Tolerance of the lugworm (Arenicola marina) to sulfide. Neth J Sea Res 14:200-207

Hauschild K (1996) Die sauerstoffabhängige Entgiftung von Sulfid zu Thiosulfat und dessen Ausscheidung beim Wattwurm Arenicola marina L. PhD dissertation, HeinrichHeine-Universität, Düsseldorf

Herreid CF II (1980) Hypoxia in invertebrates. Comp Biochem Physiol 67A:311-320

Hochachka PW, Somero GN (1984) Biochemical adaptation. Princeton University Press, Princeton

Howarth RW, Giblin A, Gale J, Petersen BJ, Luther GW III (1983) Reduced sulfur compounds in the pore waters of a New England salt marsh. Ecol Bull 35:135-152

Jahn A, Theede $H$ (1997) Different degrees of tolerance to hydrogen sulfide in populations of Macoma balthica (Bivalvia, Tellinidae). Mar Ecol Prog Ser 154:185-196

Jahn A, Gamenick I, Theede H (1996) Physiological adaptations of Cyprideis torosa Jones 1850 (Crustacea, Ostracoda) to hydrogen sulfide. Mar Ecol Prog Ser 142:215-223

Johns AR, Taylor AC, Atkinson RJA, Grieshaber MK (1997) Sulphide metabolism in thalassinidean crustacea. J Mar Biol Assoc UK 77:127-144

Levin LA, Caswell H, Bridges T, DiBacco C, Cabrera D, Plaia G (1996) Demographic responses of estuarine Polychaetes to pollutants: life table response experiments. Ecol Appl 6(4): 1295-1313

Levitt JM, Arp AJ (1991) The effects of sulfide on the anaerobic metabolism of two congeneric species of mudflat clams. Comp Biochem Physiol 98B:339-347

Oeschger R (1990) Long-term anaerobiosis in sublittoral marine invertebrates from the Western Baltic Sea: Halicryptus spinulosus (Priapulida), Astarte borealis and Arctica islandica (Bivalvia). Mar Ecol Prog Ser 59: $133-143$

Oeschger R, Vetter RD (1992) Sulfide detoxification and tolerance in Halicryptus spinulosus (Priapulida): a multiple stratecy. Mar Ecol Prog Ser 86:167-179

Pearson M. Pearson TH (1991) Variations in populations of Capitella capitata (Fabricius, 1780) (Polychaeta) from the West Coast of Scotland. Ophelia Suppl 5:363-370

Pearson TH, Rosenberg R (1978) Macrobenthic succession in relation to organic enrichment and pollution of the marine environment. Oceanogr Mar Biol Annu Rev 16:229-311

Pörtner HO (1982) Biochemische und physiologische Axpassungen an das Leben im marinen Sediment: Untersuchungen am Spritzwurm Sipunculus nudus L. PhD dissertation, Heinrich-Heine-Universität, Düsseldorf

Pörtner HO, Grieshaber MK (1993) Critical $\mathrm{PO}_{2}$ (s) in oxyconforming and oxyregulating animals: gas exchange, metabolic rate and the mode of energy production. In: Eduardo J, Bicudo PW (eds) The vertebrate gas transport cascade. Adaptations to environment and mode of life. CRC Press, Boca Raton, p 330-357

Prosser CL (1973) Comparative animal physiology, 2nd edn. Saunders, Philadelphia
Qian PY, Chia FS (1991) Effects of food concentration on larval growth and development of two polychaete worms, Capitella capitata (Fabr.) and Polydora ligni (Webster). Bull Mar Sci 48:478-485

Revsbech NP, Ward DM (1983) Oxygen microelectrode that is insensitive to medium chemical composition: use in acid microbial mat dominated by Cyandium caldarium. Appl Environ Microbiol 45:755-759

Sachs L (1984) Angewandte Statistik. Springer, Berlin

Sanders HL, Grassle JF, Hampson GR, Morse LS, GarnerPrice S, Jones CC (1980) Anatomy of an oil spill: long term effects of the grounding of the barge Florida off West Falmouth, Massachusetts. J Mar Res 38:265-380

Schöttler U, Grieshaber MK (1988) Adaptation of the polychaete worm Scoloplos armiger to hypoxic conditions. Mar Biol 99:215-222

Schöttler U, Surholt B, Zebe E (1984) Anaerobic metabolism in Arenicola marina and Nereis diversicolor during low tide. Mar Biol 81:69-73

Somero GN, Childress JJ, Anderson AE (1989) Transport, metabolism and detoxification of hydrogen sulfide in animals from sulfide-rich marine environments. Rev Aquat Sci 1:591-614

Tenore KR (1977) Growth of Capitella capitata cultured on various levels of detritus derived from different sources. Limnol Oceanogr 22(5):936-941

Tenore KR, Chesney EJ Jr (1985) The effects of interaction of rate of food supply and population density on the bioenergetics of the opportunistic polychaete, Capitella capitata (type I). Limnol Oceanogr 30:1188-1195

Theede H (1973) Comparative studies on the influence of oxygen deficiency and hydrogen sulfide on marine bottom invertebrates. Neth J Sea Res 7:244-252

Theede H, Ponat A, Hiroki K. Schlieper C (1969) Studies on the resistence of marine bottom invertebrates to oxygendeficiency and hydrogen sulfide. Mar Biol 2:325-337

Theede H, Schaudinn J, Saff F (1973) Ecophysiological studies on four Nereis species of the Kiel Bay. Oikos Suppl 15: 246-252

Thiermann F, Akoumianaki J, Hughes A, Giere O (1997) Benthic fauna of a shallow water gaseohydrothermal vent area in the Aegean sea (Milos/Greece). Mar Biol 128(1): $149-159$

Tsutsumi $\mathrm{H}$ (1987) Population dynamics of Capitella capitata (Polychaeta, Capitellidae) in an organic polluted grove. Mar Ecol Prog Ser 36:139-149

Tsutsumi H, Fukunaga S, Fujita N, Sumida M (1990) Relationship between growth of Capitella sp. and organic enrichment of the sediment. Mar Ecol Prog Ser 63: $157-162$

Vetter RD, Wells ME, Kurtsman AL, Somero GN (1987) Sulfide detoxification by the hydrothermal vent crab Bythograea thermydron and other decapod crustaceans. Physiol Zool 60:121-137

Vismann B (1990) Sulfide detoxification and tolerance in Nereis (Hediste) diversicolor and Nereis (Neanthes) virens (Annelidae: Polychaeta). Mar Ecol Prog Ser 59: $229-238$

Vismann B (1991) Sulfide tolerance: physiological mechanisms and ecological implications. Ophelia 34:1-27

Vismann B (1996) Sulfide exposure experiments: the sulfide electrode and a set-up automatically controlling sulfide, oxygen and pH. J Exp Mar Biol Ecol 204:131-140

Völkel S, Grieshaber MK (1992) Mechanisms of sulfide tolerance in the peanut worm Sipunculus nudus (Sipunculida) and in the lugworm Arenicola marina (Polychaeta) J Comp Physiol 162B:469-477 
Völkel S, Grieshaber MK (1994) Oxygen dependent sulfide detoxification in the lugworm Arenicola marina. Mar Biol 118:137-147

Völkel. S, Grieshaber MK (1996) Mitochondrial sulfide oxidation in Arenicola marina. Evidence for alternative electron pathways. Eur $J$ Biochem 235:231-237

Warren LM (1977) The ecology of Capitella capitata in British waters. J Mar Biol Assoc UK 57:151-159

Warren LM (1984) How intertidal polychaetes survive

Editorial responsibility: Otto Kinne (Editor),

Oldendorf/Luhe, Germany at low tide. In: Hutchings $P$ (ed) Proc 1st Int Polych Conf, Linnean Soc of New South Wales, Sydney, p 238-253

Wu BL, Qian PY, Zhang SL (1991) Morphology, reproduction, ecology and allozyne electrophoresis of three Capitella sibling species in Qingdao (Polychaeta: Capitellidae). Ophelia Suppl 5:391-400

Zhang SL, Wu BL (1988) Taxonomy of the Capitella capitatacomplex (Polychaeta). Mar Sci Bull 1:187-192

Submitted: May 4, 1998; Accepted: August 21, 1998

Proofs received from author(s): December 7, 1998 